\title{
A letter from Lagrange to his father
}

\author{
Livia Giacardi · Franco Pastrone
}

Published online: 10 April 2014

(c) Centro P.RI.ST.EM, Università Commerciale Luigi Bocconi 2014

\begin{abstract}
This article presents a reproduction, transcription and translation of a letter written by Lagrange to his father, Giuseppe Francesco Luigi, conserved in the Biblioteca speciale di matematica "Giuseppe Peano" in Turin. Dated 12 December 1779, the letter belongs to the period that is scientifically most fertile for Lagrange, that of his stay in Berlin (1766-1787). Although the letter does not discuss his work, it makes evident some of the traits of his personality that allowed him to achieve the excellent results of his research.
\end{abstract}

Keywords Lagrange $\cdot$ Personality · Family ·

Correspondence

The letter of Lagrange dated Berlin, 12 December 1779, the first page of which is reproduced here (Fig. 1), is addressed to his father, Giuseppe Francesco Luigi. ${ }^{1}$ It was thus written during the period in Berlin (1766-1787), which, scientifically speaking, was the most fertile for the illustrious scientist from Turin. The letter is conserved in Turin, in the "Fondo Rari" of the Biblioteca speciale di Matematica "Giuseppe Peano".

Like many of the letters to his family, this one too, even while not adding any details to what is known about Lagrange's scientific life, makes quite evident some of the aspects of his personality: his detachment, his self-

L. Giacardi $(\bowtie) \cdot$ F. Pastrone

Dipartimento di matematica, Università di Torino,

Via Carlo Alberto, 10, 10123 Turin, Italy

e-mail: livia.giacardi@unito.it

F. Pastrone

e-mail: franco.pastrone@unito.it discipline, his love of tranquillity and a kind of egotistical indifference, qualities that permitted him to attain the extremely high level of his research results.

Here we give a faithful transcription of the original text, which shows the peculiarities of Lagrange's French spelling, followed by the translation in English.

\section{Transcription of the original letter}

à Berlin le 12 Decembre 1779

Monsieur, mon tres cher Pere

Comme cette lettre ne vous parviendra que vers la renouvellement de l'année, je la commence par vous prier de recevoir tous les voeux que je fais pour vous du fond de mon coeur a cette occasion. Quoique je n'aie point reçu de vos nouvelles depuis votre lettre du 30 Janvier, a laquelle j'ai repondu dans le mois de Mars, je ne doute pas que vous ne vous soyez toujours assez bien porté, et j'attribue votre silence a ce que vous n'aviez peut etre rien de nouveau ni de particulier a me mander. C'est aussi la raison pourquoi je ne vous ecris pas plus souvent; j'en use de meme avec tous mes amis, et je ne trouve pas mauvais qu'ils me rendent la pareille pourvu que leurs sentimens a mon egard n'en sojent point alterés. Ma santé se soutient jusqu'a présent assez bien, et ce qu'il y a de singulier c'est que les hivers de ce pais qui sont quelque fois assez rudes, non seulement ne m'incommodent point, mais me sont en quelque façon beaucoup plus favorables que les etés.

\footnotetext{
1 The corpus of Lagrange's letters to his family was published in the original versions in [1], and in an Italian translation in [2]. The present letter of Lagrange to his father does not appear in those collections, and was first published in [3].
} 
Fig. 1 Reproduction of the first page of letter from Lagrange to his father

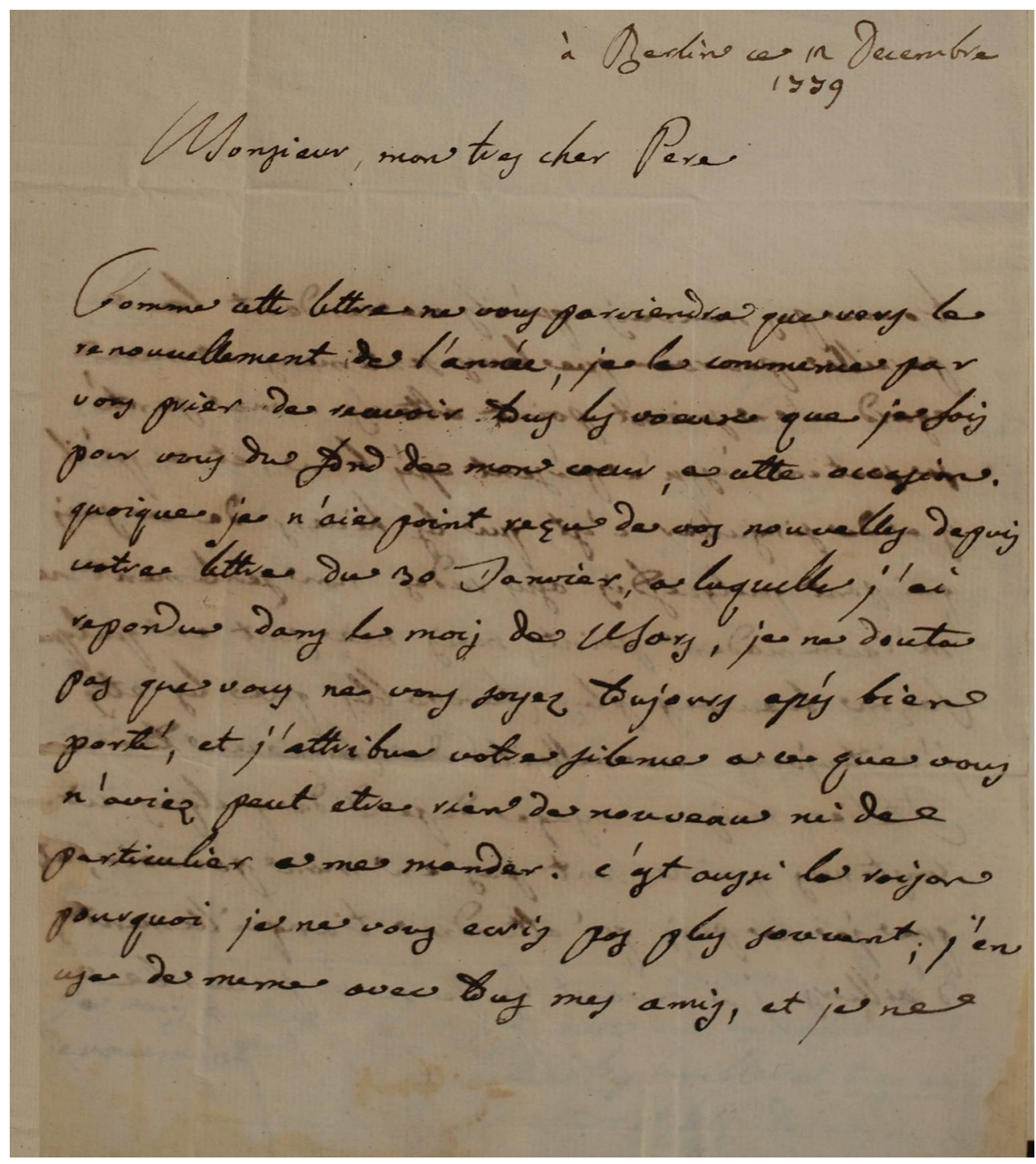

J'ai toujours une velléité de faire un tour en Italie, mais le voyage depend de quelques circonstances qui ne sont pas en mon pouvoir: et que je ne puis qu'attendre tranquillement; d'ailleurs j'ai devant les yeux le proverbe chi sta ben non si muova, ce qui joint à certaine indolence que je dois à l'age ou au climat fait que je ne veux rien hater, de crainte de m'exposer a des regrets. Je vous recommande d'avoir bien soin de votre santé. Vous avez le bonheur de voir toute votre famille placée et de pouvoir couler vos jours avec plus de douceur et de tranquillité que vous n'avez pu ou su le faire dans votre jeunesse; je vous exhorte a profiter de ce dernier avantage et a reparer du mieux que vous pouvez le tems perdu. La tranquillité et le repos sont les plus grands peut etre les seuls biens de ce monde. Je vous embrasse et je suis avec un inviolable devouement.

Votre tres humble et tres obeiss.

serviteur et fils delaGrange.

\section{Translation}

Berlin, 12 December 1779

Sir, my very dear Father,

Since this letter will arrive to you only towards the renewal of the year, I begin by begging you to receive all the wishes that I have for you from the bottom of my heart on this occasion. Although I have not received any news from you since the letter of 30 January, to which I replied during the month of March, I have no doubt that you have been ever well and I attribute your silence to the fact that you might not have anything either new or particular to tell me. This is also the reason why I have not written you more often; I use the same way with all my friends and I do not find it ill if they do likewise to me, provided that their sentiments in my regard are not altered in any way. My health at present is quite well, and what is singular is that the winters in this country, which are sometimes quite 
harsh, not only do not inconvenience me at all, but are in someway more favourable than the summers.

I always have a inclination to a make a trip to Italy, but the trip depends on some circumstances that are not in my power: and I can only wait quietly, besides I always keep in mind $^{2}$ the proverb chi sta ben non si muova (one who is fine does not move), which joined to a certain indolence due to age or to the climate makes it so that I wish to hasten nothing, for fear of exposing myself to regret. I recommend you take good care of your health. You have the happiness of seeing all of your family (well) placed and can pass your days with more sweetness and tranquillity that you were able to do in your youth; I exhort you to profit from this final advantage and make up the best you can for time lost. Tranquillity and repose are the greatest, and perhaps the only good possessions of this world. I embrace you and I am yours with an inviolable devotion.

Your very humble and very obedient.

servant and son delaGrange.

(Translated from the Italian by Kim Williams).
2000 to 2008; she is currently a member of the Council. She is also a member of the Scientific Commission of the Italian Mathematical Union and is among the editors of journal La Matematica nella Società e nella Cultura.

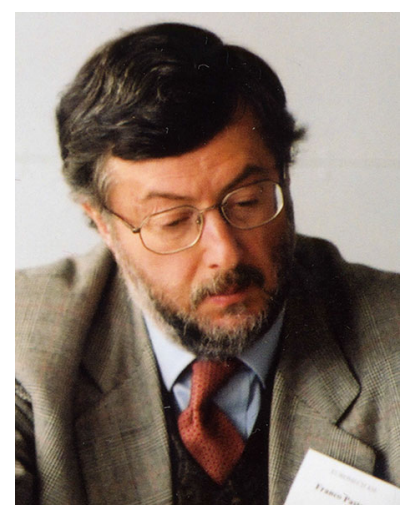

Franco Pastrone is a retired full professor of Mathematical Physics. He has a contract with the SSST to teach a course on Mathematical Models. His research work concerns nonlinear elasticity and non-linear wave propagation in complex solids. He also has an interest in the history of mathematics. He is the author of more than 80 research papers published in Italian and international journals. He is a National Member of the Accademia delle Scienze di Torino and member of the Accademia Peloritana dei Pericolanti di Messina $\mathrm{He}$ is the president of the Associazione Subalpina Mathesis and organizes several activities related to this association. Since 2007 he has been a member of the International Advisory Board of CENS, Tallinn, Estonia.

\section{References}

1. Borgato, M.T., Pepe, L.: Sulle lettere familiari di Giuseppe Luigi Lagrange. Bollettino di Storia delle Scienze Matematiche IX: 192-318 (1989)

2. Borgato, M.T., Pepe, L.: Lagrange Appunti per una biografia scientifica. La Rosa Editrice, Turin (1990)

3. Giacardi, L., Pastrone, F.: Una lettera inedita di Lagrange al padre. Atti della Accademia delle Scienze di Torino 132, 1-9 (1998)

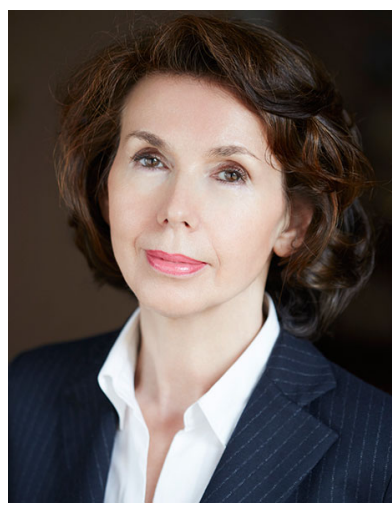

Livia Giacardi is a full professor of History of Mathematics at the University of Torino. Her research concerns the history of mathematics and history of mathematics education (19th and 20th centuries). She is the author of numerous essays, critical editions of unpublished documents, and books for both specialists and for a more general public. She is also editor of several CDs and websites devoted to the history of mathematics.

She collaborates with the International Group for Research on the History of Mathematics Education. She has been the Secretary of the Italian Society for the History of Mathematics from its founding in

\footnotetext{
${ }^{2}$ Literally, "I have in front of my eyes".
} 